\title{
Phylogeny of the Anomura (Decapoda, Crustacea): Spermatozoa and spermatophore morphological evidence
}

\author{
Christopher C. Tudge \\ Crustacean Laboratory, Museum of Victoria, 71 Victoria Crescent, Abbotsford, Vic. 3067, Australia
}

Keywords: Anomura, phylogeny, spermatozoa, spermatophore, ultrastructure, hermit crabs

\begin{abstract}
A phylogenetic analysis of selected anomuran, thalassinidean, and other decapod crustacean taxa, based on spermatozoal ultrastructural characters and spermatophore morphological characters, was performed and the following relationships of the taxa are elucidated from the trees produced. The Anomura are not a monophyletic assemblage, with the lomoid Lomis being exclusive of the remainder of the anomuran taxa, and the thalassinid Thalassina included in the anomuran clade. The synapomorphy joining the majority of the conventional anomuran taxa (Lomis excluded) is the cytoplasmic origin of the microtubular arms. When the palinurid and thalassinoid representatives are separately designated as outgroüs, the Astacidea and Brachyura jointly formed a sister group to the Anomura. The superfamilies Thalassinoidea, Paguroidea, and Galatheoidea are not monophyletic groups. In all analyses the anomuran families Coenobitidae and Porcellanidae each form a monophyletic group. The paguroid family Diogenidae is paraphyletic, with the genera Clibanarius and Cancellus separate from a single clade containing the remaining diogenid genera. The families Paguridae and Parapaguridae form a monophyletic clade with the exception of Porcellanopagurus. The two representatives of the family Chirostylidae (Eumunida and Uroptychus) fail to associate with the other species in the Galatheoidea. The taxa in the family Galatheidae are not a monophyletic assemblage. The only investigated hippoid Hippa is portrayed as the sister group to the remainder of the anomuran taxa (with the exception of Lomis).
\end{abstract}

\section{Résumé}

Une analyse phylogénétique d'une sélection de taxons d'Anomures, de Thalassinides et d'autres Décapodes, basée sur des caractères ultrastructuraux des spermatozoïdes et sur des caractères morphologiques du spermatophore, a été entreprise, et les arbres produits permettent d'élucider plusieurs aspects concernant la parenté entre taxons. Les Anomures ne sont pas un taxon monophylétique: le genre lomoĩde Lomis est exclu de ce groupe, tandis que le genre thalassinide Thalassina y est inclu. La synapomorphie pour la majorité des taxons conventionnels d'Anomures.(Lomis exclu) est l'orígine cytoplasmique des branches microtubulaires. Si des représentants des Palinurides et des Thalassinoïdes sont séparément désignés comme "outgroups", les Astacidea + Brachyura forment un groupe-frère pour les Anomura. Les superfamilles Thalassinoidea, Paguroidea et Galatheoidea ne sont pas des groupes monophylétiques. Les analyses montrent que les familles d'Anomures Coenobitidae et Porcellanidae sont des groupes monophylétiques. La famille de Paguroïdes Diogenidae est paraphylétique, les genres Clibanarius et Cancellus devant ếtre séparés du clade contenant le reste des genres diogenides. Les familles Paguridae et Parapaguridae forment un clade monophylétique - à l'exception du genre Porcellanopagurus. Les deux représentants de la famille Chirostylidae (Eumunida et Uroptychus) ne peuvent pas être associés avec les autres espèces des Galatheoidea. Les taxons de la famille Galatheidae ne forment pas un groupe monophylétique. Le seul Hippoïde étudié, Hippa, est considéré comme groupe-frère des autres taxons d'Anomures (Lomis excepté).

\section{Introduction}

The use of spermatozoal ultrastructure in taxonomy and phylogeny is now firmly established as a valid means of investigating phylogenetic relationships in various animal groups. There are many phyla in which advances have been made in phylogenetic studies by using spermatozoal ultrastructure. Recent examples include studies in the Platyhelminthes (Ehlers, 1985; Justine, 1991); Polychaeta (Jamieson \& Rouse, 1989); Oligochaeta (Jamieson, 1981, 1983); Mollusca (Healy, 1988); fish (Jamieson, 1991b; Mattei, 1991), and 
Amniota (Healy \& Jamieson, 1992; Jamieson \& Healy, 1992; Jamieson, 1995a, b).

Within the Crustacea, studies on spermatozoal ultrastructure in representatives of the Pentastomida (Wingstrand, 1972; Storch \& Jamieson, 1992) have confirmed that the pentastomids are crustaceans, a view endorsed by molecular biology (Abele et al., 1989). Similarly, spermatozoal ultrastructure has been shown (Jamieson \& Tudge, 1990; Jamieson, 1991a, 1994; Jamieson et al., 1995) to support Guinot's re-classification of the Brachyura (Guinot, 1977, 1978) into Podotremata, Heterotremata (sensu lato), and Thoracotremata, based on differential location of the male and female gonopores.

The phylogenetic significance of crustacean spermatozoa had been recognized by Koltzoff (1906) and later, Wielgus (1973). Koltzoff (1906: 424) was one of the first workers to construct a phylogeny of crustaceans based on spermatozoal structure at the light microscope level. To the different sperm types encountered he assigned a binomen consisting of the "generic" name Spermia and a descriptive "species" name and placed this binomen on the nodes and branches of his phylogenetic tree. The crustacean taxa included in his study were Mysis, Euphausia, Natantia, Galatheidea, Paguridea, Thalassinidea, Astacus, Loricata, Brachyura, Oxystomata, and Dromiidea. Some of the significant relationships apparent in Koltzoff's phylogenetic tree were the separation of Mysis from the decapods at the node Spermia flagellifera, recognizing the presence of what is now termed a pseudoflagellum (Jamieson, 1987) in the spermatozoa of Mysis. The anomuran groups Galatheidea and Paguridea were designated Spermia erecta, in recognition of the superiorly positioned, generally elongate acrosome vesicle. The Brachyura, Oxystomata, and Dromiidea were labelled Spermia cephalacantha. The latter binomen probably refers to the many nuclear arms and spikes that project laterally from around the acrosome vesicle of the spermatozoa in these groups.

The relationships among the families in the infraorder Anomura (the "Anomala" of Boas, 1880), and among representatives within families, have been the subject of several investigations at the morphological and molecular level. Of note are the phylogenetic analyses of the constituent families of the Anomura using adult and larval somatic morphology (McLaughlin, 1983b; Martin \& Abele, 1986; Richter \& Scholtz, 1994; Scholtz \& Richter, 1995) and the analyses of several members of the Anomura based on 18S rRNA nucleotide sequences by Spears \& Abele (1988) and Spears et al. (1992), 16S rRNA by Cunningham et al. (1992), and 16S rRNA and cytochrome oxidase I genes by Tam et al. (1996). Richter \& Scholtz (1994: 197) state that "the phylogenetic relationships (within the asymmetrical hermit crabs) are unresolved and seem to be very complex". While recognizing the validity of the taxon "Anomala", particularly as used by Scholtz \& Richter (1995), and not wishing to enter into debate over terminology, I prefer to use the term "Anomura" for the infraorder containing the superfamilies Galatheoidea, Paguroidea, Hippoidea, and Lomoidea, as argued by McLaughlin \& Holthuis (1985).

The value of computer programs, such as PAUP (Phylogenetic Analysis Using Parsimony) (Swofford, 1993), for phylogenetic analysis of spermatozoal and molecular characters has been well demonstrated in many animal groups (Jamieson et al., 1987; Kim \& Abele, 1990; Abele, 1991; Jamieson, 1991b, 1993, 1994, 1995a, b; Spears et al., 1992; Jamieson \& Grier, 1993; Jamieson et al., 1995). The present study investigates the interrelationships of 42 species of anomuran crab, three species of thalassinidean shrimp, and six species of other decapods using similar parsimony analysis procedures and employs 26 spermatozoal and 6 spermatophore characters.

\section{Materials and methods}

The taxa included in this analysis, with sources of character information, are displayed in Table I. Appendices A \& B describe the characters used in the parsimony analysis and the complete data matrix, respectively. Of the 32 characters employed in the analysis only one (character 19) is considered at present phylogenetically uninformative. 
Table I. Taxa included in the analysis. [ ] = source of character information.

Infraorder Thalassinideá

Axiidae: Axius glyptocercus Von Martens, 1868 [Tudge, 1995a, b]

Callianassidae: Trypaea australiensis (Dana, 1852) [Tudge, 1995a]

Thalassinidae: Thalassina squamifera De Man, 1915 [Tudge, 1995a, b]

\section{Infraorder Anomura}

Chirostylidae: Eumunida sternomaculata St. Laurent \& Macpherson, 1990 [Tudge, 1995a, b]

Uroptychus sp. [Tudge, 1995a]

Coenobitidae: Birgus latro (Linnaeus, 1758) [Tudge \& Jamieson, 1991; Tudge, 1991, 1995a]

Coenobita brevimanus Dana, 1852 [Tudge, 1991, 1995a]

Coenobita perlatus H. Milne Edwards, 1837 [Tudge, 1991, 1995a, b]

Coenobita purpureus Stimpson, 1858 [Tudge, 1995a]

Coenobita rugosus H. Milne Edwards, 1837 [Tudge, 1991, 1995a]

Coenobita variabilis McCulloch, 1909 [Tudge, 1991, 1992, 1995a]

Diogenidae: Calcinus gaimardii (H. Milne Edwards, 1848) [Tudge, 1995a]

Calcinus laevimanus (Randall, 1840) [Tudge, 1995a]

Calcinus minutus Buitendijk, 1937 [Tudge, 1991, 1995a, b]

Cancellus sp. [Tudge, 1995a, b]

Clibanarius corallinus (H. Milne Edwards, 1848) [Jamieson, 1991a; Tudge, 1991, 1992, 1995a]

Clibanarius erythropus (Latreille, 1818) [Tudge, 1995a]

Clibanarius longitarsus (De Haan, 1849) [Tudge, 1995a, b]

Clibanarius taeniatus (H. Milne Edwards, 1848) [Tudge, 1992, 1995a]

Clibanarius virescens (Krauss, 1843) [Tudge, 1991, 1992, 1995a]

Dardanus arrosor (Herbst, 1796) [Tudge, 1995a, b]

Dardanus crassimanus (H. Milne Edwards, 1836) [Tudge, 1992, 1995a]

Dardanus lagopodes (Forskål, 1775) [Tudge, 1991, 1995a]

Dardanus scutellatus (H. Milne Edwards, 1848) [Tudge, 1995a]

Dardanus sp. nov. [Tudge, 1995a] *

Diogenes custos (Fabricius, 1798) [Tudge, 1992, 1995a]

Diogenes pallescens Whitelegge, 1897 [Tudge, 1995a, b]
Strigopagurus boreonotus Forest, 1995 [Tudge, 1995a, 1996]

Galatheidae: Allogalathea elegans (Adams \& White, 1848) [Jamieson, 1991a; Tudge, 1995a]

Munida sp. [Tudge, 1995a, b]

Munidopsis sp. [Tudge, 1995a]

Hippidae: Hippa pacifica (Dana, 1852) [Matthews, 1956; Tudge, 1995a, b]

Lomidae: Lomis hirta (Lamarck, 1810) [Tudge, 1995a, b, 1997]

Paguridae: Pagurus bernhardus (Linnaeus, 1758) [Tudge, 1995a]

Pagurus chevreuxi (Bouvier, 1896) [Tudge, 1995a, b]

Pagurus hirtimanus Miers, 1880 [Tudge, 1991, 1995a]

Pagurus prideaux Leach, 1815 [Tudge, 1995a]

Porcellanopagurus sp. [Tudge, 1995a, b]

Xylopagurus sp. nov. [Tudge, 1995a, b] *

Parapaguridae: Sympagurus sp. [Tudge, 1995a, b]

Porcellanidae: Aliaporcellana suluensis (Dana, 1852) [Tudge, 1995a, b; Tudge \& Jamieson, 1996a]

Petrolisthes armatus (Gibbes, 1850) [Tudge, 1995a; Tudge \& Jamieson, 1996b]

Petrolisthes lamarckii (Leach, 1820) [Jamieson, 1991a; Tudge, 1995a; Tudge \& Jamieson, 1996b]

Pisidia longicornis (Linnaeus, 1767) [Retzius, 1909; Mouchet, 1931; Tudge, 1995a; Tudge \& Jamieson, 1996a]

Polyonyx transversus (Haswell, 1882) [Tudge, 1995a, b; Tudge \& Jamieson, 1996b]

Infraorder Astacidea

Astacidae: Pacifastacus leniusculus Dana, 1852 [Dudenhausen \& Talbot, 1982, 1983]

Homaridae: Homarus americanus Milne Edwards, 1837 [Talbot \& Chanmanon, 1980a, b]

Infraorder Palinura

Palinuridae: Panulirus argus (Latreille, 1804) [Talbot \& Summers, 1978]

Scyllaridae: Thenus orientalis (Lund, 1793) [Burton, 1995; Jamieson, pers. comm.]

Infraorder Brachyura

Majidae: Menaethius monoceros (Latreille, 1825) [Jamieson, 1991a, pers. comm.]

Portunidae: Portunus pelagicus (Linnaeus, 1766) [Jamieson, 1989; Jamieson \& Tudge, 1990]

*Probable new species from the western Pacific Ocean; currently lodged in the MNHN, Paris, awaiting identification (Dardanus sp. nov. - Pg 5468, Xylopagurus sp. nov. - Pg 5337).

\section{Phylogenetic analysis}

The phylogenetic analysis was performed using PAUP version 3.1.1 (Swofford, 1993), utilizing a data matrix originally set up in MacClade version 3 (Maddison \& Maddison, 1992). Heuristic search analyses were performed with the following options applied. Addition sequence: simple; one tree held at each step during stepwise addition; tree-bisection-reconnection (TBR) branch-swapping performed; MULPARS option in effect; steepest descent option not in effect; branches having maximum length zero collapsed to yield polytomies; topological constraints not enforced; trees unrooted; multi-state taxa interpreted as polymorphism; character-state 'optimization: accelerated transformation (ACCTRAN). All characters unordered and unscaled.

As suggested by Hillis (1991) and demonstrated in Hillis \& 
Huelsenbeck (1992), the strength of the phylogenetic signal (measure of information content) for a given data set can be interpreted from the skewness (or otherwise) of the distribution of all the given trees. A symmetrical (bell-curve) distribution indicates that the data are random, and the most parsimonious tree obtained from these data would not necessarily reflect the phylogenetic history of the taxa used. Notwithstanding recent criticism of the skewness criterion as a measure of phylogenetic signal (Källersjö et al., 1992), it is applied in the present study.

Using the exhaustive search setting the distribution of all trees can be obtained from a given data set. An alternative method of estimating the skewness of tree distribution is to use the random trees option. A sample size of 1000 random trees was chosen as it is the minimum number needed to obtain a reasonably accurate estimate of skewness (Jamieson, 1994).

Two palinurids, two astacids, and three thalassinoids were variably used as the outgroup. The palinurid taxa Panulirus and Thenus were used as the outgroup in the principle analysis because of the relatively undisputed basal position of the Palinura within the Reptantia, based on fossil (Glaessner, 1969), molecular (Vaughn \& Traeger, 1976) and somatic morphological (Scholtz \& Richter, 1995) evidence. As with the Palinura, the Astacidea previously have been designated a basal or stem position within the evolution of the reptantian decapods. Makarov (1962: 23) stated "The group from which all Anomura originated was that of the Astacura, ..." and Glaessner (1969) indicated that the fossil record of the Astacidea is as old, if not older than, that of the Palinura (excluding the Glypheoidea).

The relationship of the infraorder Thalassinidea to the other decapod infraorders has long been the subject of debate. The thalassinoids are considered by some crustacean workers (Burkenroad, 1963; Bauer, 1986) to have important links with the other decapod infraorders and to have played an integral role in the evolution of the Decapoda. They have previously been linked with the infraorder Anomura on both larval (Gurney, 1942; MacDonald et al., 1957) and adult morphological (de Saint Laurent, 1973; Martin \& Abele, 1986) evidence. In recent cladistic analyses of adult somatic characters the thalassinoids are depicted as the sister group of the Anomura (Poore, 1994; Scholtz \& Richter, 1995).

\section{Results}

An heuristic analysis of 51 decapod taxa using 32 spermatozoal and spermatophore characters (using the options listed above) gave 26 equally parsimonious trees using the outgroup method. The phylogram of the $50 \%$ majority rule consensus tree of the 26 trees is shown in Fig. 1. The palinurid genera Thenus and Panulirus were designated as the outgroup. Tree length $=136$ steps; consistency index $(\mathrm{CI})=0.493$; homoplasy index $(\mathrm{HI})=0.603$; retention index $(\mathrm{RI})=0.768$; rescaled consistency index $(\mathrm{RC})=0.378$. Some higher taxonomic groupings, relevant characters and contentious clades and taxa are indicated.

The cladogram of the same consensus tree is shown in Fig. 2, with clades not supported by $100 \%$ of trees indicated.

Heuristic analyses (with identical parameters as the above analysis), using the two astacid genera Homarus and Pacifastacus and, separately, the three thalassinoid genera Axius, Thalassina, and Trypaea as outgroups, each produced a 50\% majority rule consensus tree of nearly identical topology to Figs. 1 and 2. Each of the consensus trees was 136 steps long and was calculated from 26 equally parsimonious trees. For brevity these trees have not been illustrated.

The distribution of 1000 random trees for the analysis gave a g1 value of -0.43 . The negative value indicates that the data are not random in terms of the table given in Hillis \& Huelsenbeck (1992), and therefore the phylogenetic signal is significant.

\section{Discussion}

\section{Infraorder Anomura}

The Anomura is not shown to be a monophyletic assemblage (Fig.1, point B). One excluded taxon is Lomis hirta (Lomidae), which is depicted in a very basal position, reflecting a plesiomorphic spermatozoal morphology (Tudge, 1997). Also, the questionable placement of the thalassinid, Thalassina squamifera, with the hippoid, Hippa pacifica, within the "anomuran" clade makes the Anomura paraphyletic. For both Lomis and Thalassina the spermatozoal and spermatophore morphology is not fully known or is contentious (Tudge, 1995a, b), and further study may alter these relationships.

The clade containing the vast majority of the anomuran taxa (Fig. 1, point B) is primarily characterized by the unambiguous character state change from spermatozoal microtubular arms of nuclear origin to such arms being cytoplasmic in origin (see character 1, Appendix A). This character is equivocal in Lomis and Thalassina (see data matrix, Appendix B) and may go some way 
towards explaining their contentious placement (Figs. 1 \& 2).

\section{Infraorders Palinura, Astacidea, and Brachyura}

The six taxa in these decapod categories were added to the analyses to provide further comparison with the Anomura. The paraphyletic relationship of the Brachyura to the Anomura (Figs. 1 \& 2) only partially conforms with previous opinion (see Glaessner, 1969; Scholtz \& Richter, 1995). The sister-group relationship of the Astacidea to the Anomura (Figs. 1 \& 2) is more contentious but is supportive of a sister-group relationship between Astacidea ("Astacida") and Anomura/ Brachyura ("Meiura") proposed by Scholtz \& Richter (1995) and the derivation of the Anomura from the Astacidea (as "Astacura") by Makarov (1962). The very basal position of the palinurid representatives (when not used as an outgroup), previously supported by fossil (Glaessner, 1969) and molecular (Vaughn \& Traeger, 1976) evidence, and their association with the thalassinoid Trypaea (Figs. 1 \& 2), are of considerable interest. This latter association is supported by the shared absence of the perforatorial chamber in the spermatozoa (Fig. 1, point A).

\section{Infraorder Thalassinidea}

The three representatives in this taxon were designated as the outgroup for one analysis based on previous indications of their sister-group relationship with the Anomura (Martin \& Abele, 1986; Poore, 1994). The outgroup was unable to be retained as a monophyletic clade as both Thalassina and Trypaea shifted to the ingroup, allying themselves with Hippa and Panulirus, respectively (these latter associations were maintained in the analysis shown in Figs. 1 \& 2). In all analyses, the Thalassinoidea were never retained as a monophyletic group. Paraphyly of these thalassinoids reflects the very diverse spermatozoal morphologies exhibited by the three representatives (Tudge, 1995a, b), each from a separate superfamily (Poore, 1994). Monophyly of the Thalassinidea has been proposed by Poore (1994) and Scholtz \& Ríchter (1995) but has previously been disputed by Gurney (1942) and de Saint Laurent (1973). This latter view of paraphyly of the Thalassinidea would here appear to receive support from spermatozoal ultrastructure.

\section{Superfamily Paguroidea}

The members of the superfamily Paguroidea (comprising the families Coenobitidae, Diogenidae, Paguridae, and Parapaguridae) are not shown to be a monophyletic group (Figs. $1 \& 2$ ). The inclusion of some members of the superfamily Galatheoidea within the same clade indicates paraphyly for both superfamilies. This is in contrast with the monophyletic Paguroidea suggested by McLaughlin (1983b) and Richter \& Scholtz (1994) using adult somatic morphological characters in their analyses. Admittedly though, the monophyly of the Paguroidea is only compromised spermatologically by the inclusion of the investigated galatheids and chirostylids, both sharing the apomorphic possession of three microtubular arms with the spermatozoa of the paguroids (Fig. 1, point D). The separation of the Paguroidea into the traditional "right" and "lefthanded" hermit crabs is not upheld. The inclusion of the Clibanarius clade (Fig. 1, point E), diogenid or "left-handed" hermit crabs, within the clade containing the members of the Paguridae, which are considered "right-handed", marrs this classical dichotomy. The general placement of the major genera in the Paguroidea is consistent with the intuitive phylogenetic trees previously suggested by the author (Tudge, 1991, 1992).

Family Coenobitidae. The six species in the two genera investigated in this family, Birgus and Coenobita, consistently form a monophyletic group, and, interestingly, this is a subclade of the majority of the diogenid members (Figs. $1 \& 2$ ). This close association between members of the Coenobitidae and Diogenidae has previously been suggested (McLaughlin, 1983b; Tudge, 1991, 1992; Richter \& Scholtz, 1994). Monophyly of the Coenobitidae is supported on somatic morphological grounds by McLaughlin (1983b), Martin \& Abele (1986), and Richter \& Scholtz (1994) and now strongly supported spermatologically.

Family Diogenidae. The investigated members of this morphologically diverse family did not 


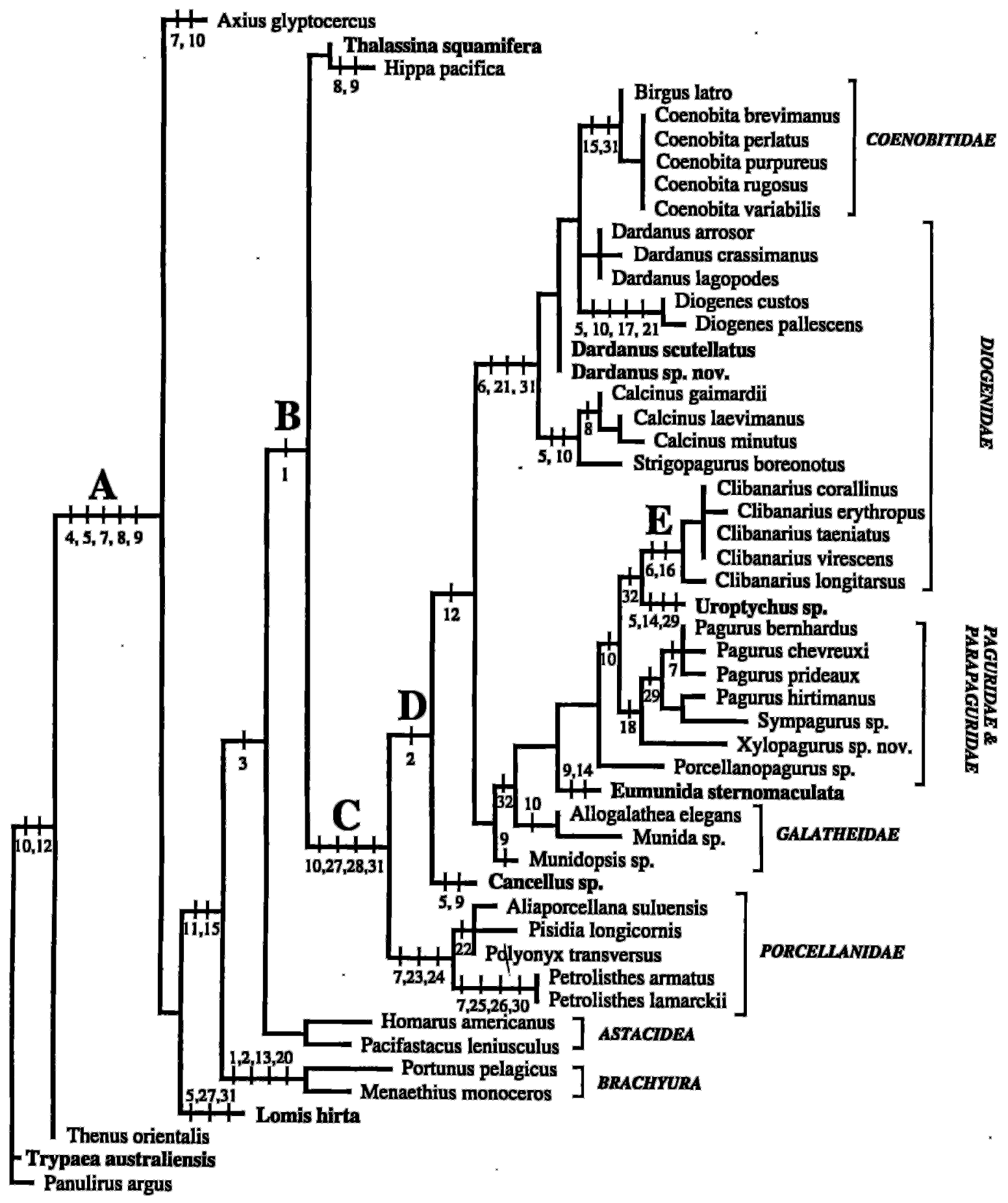

Fig. I. Phylogram of 50\% majority rule consensus tree of 26 equally parsimonious trees obtained from an heuristic analysis of 51 taxa using 32 combined spermatozoal and spermatophore characters, using the outgroup method. Tree length $=136$; consistency index $(\mathrm{CI})$ $=0.493$; homoplasy index $(\mathrm{HI})=0.603$; retention index $(\mathrm{RI})=0.768$; rescaled consistency index $(\mathrm{RC})=0.378$. Some higher taxonomic categories are indicated (brackets) along with relevant, unambiguous, apomorphic character changes (numerals), contentious taxa (species names in bold), and nodes of specific interest (bold capitals). Point $\mathbf{A}=$ characters associated with the development of the perforatorial chamber in the spermatozoa. Point B = the "Anomura" characterized by the shift of microtubular arms from the nucleus to the cytoplasm. Point $\mathrm{C}=$ the appearance of the pedunculate spermatophore. Point $\mathrm{D}=$ the restriction of the number of microtubular arms to three. Point $\mathrm{E}=$ the Clibanarius species clade separated from the other traditional diogenids. 


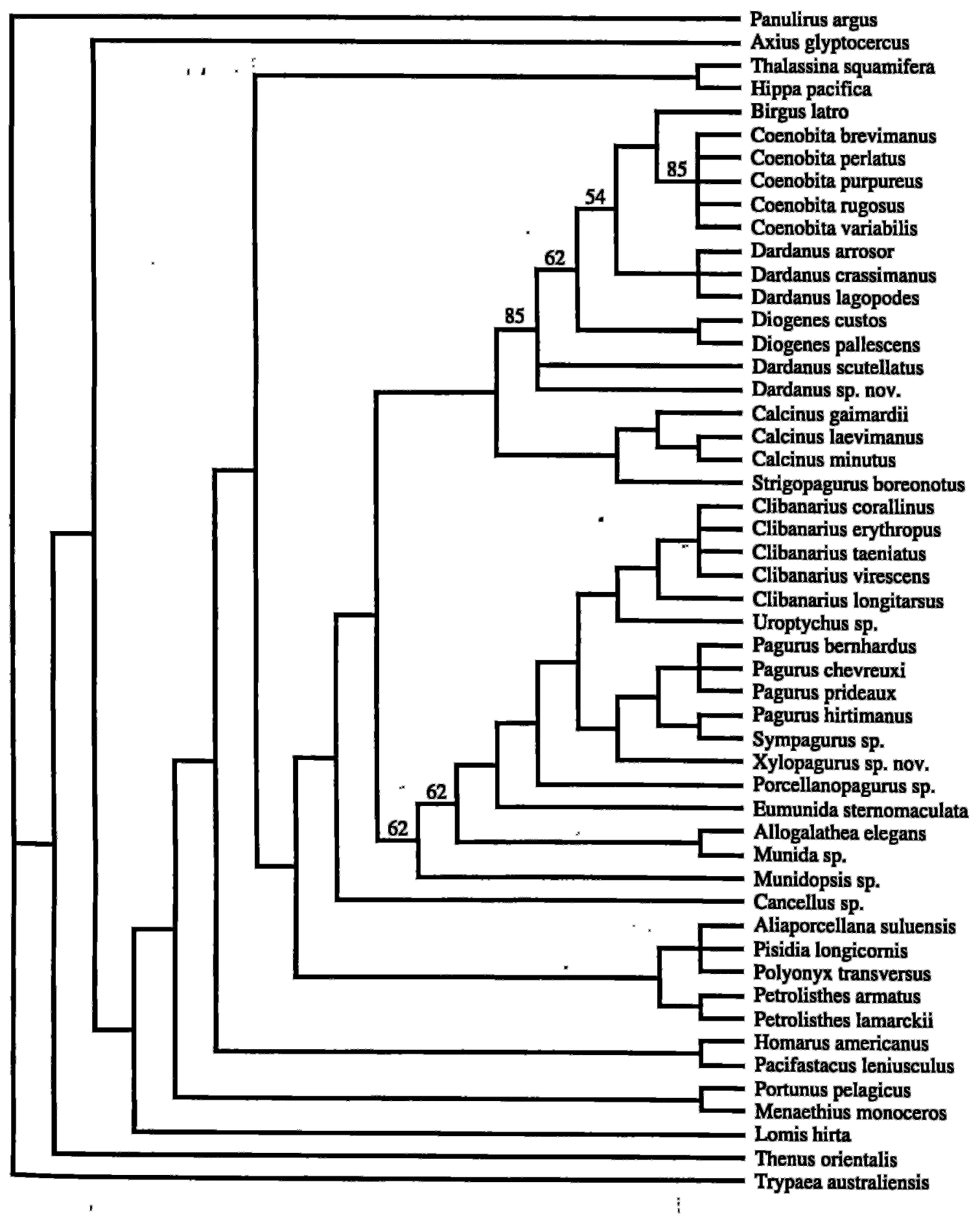

Fig. 2. Cladogram of same $50 \%$ majority rule consensus tree as Fig. 1. Clades are supported by $100 \%$ of trees unless otherwise indicated. 
form a single clade but were split between two clades (Figs. 1 \& 2), the genera Clibanarius (Fig. 1, point E) and Cancellus being separated from the remainder. The single representative of the genus Cancellus exhibits several unusual spermatozoal features (Tudge, 1995a, b) that separate it from the Diogenidae (of which it is conventionally a member) and place it in a basal position in relation to the other paguroids. The heterogeneity of the genera within the family Diogenidae and the difficulty in determining their affinities has been expressed by Forest $(1984,1995)$, but he considers the family to be an ancient monophyletic group. Richter \& Scholtz (1994) have suggested that the Diogenidae are most likely paraphyletic (as indicated in the present study), but they presented no supporting evidence.

Family Paguridae. The representatives of the family Paguridae are not retained as a monophyletic group. The inclusion of the parapagurid Sympagurus sp. in the Pagurus clade and the exclusion of Porcellanopagurus sp. make the family paraphyletic, at least in terms of spermatological features (Figs. $1 \& 2$ ). The pagurid clade (with the exception of Porcellanopagurus) is characterized by the presence of one or more reticulated acrosome zones (character 18) in the spermatozoa (Fig. 1), although the exact homology of this character between all the inclusive genera is uncertain. The Pagurus-Sympagurus clade is defined by the presence of the accessory ampulla (character 29) in the spermatophore of the examined species (Fig. 1). Further investigation of the occurrence of the accessory ampulla throughout representatives in the Paguridae and related families may confirm the validity of this character for phylogenetic analysis. The exclusion of Pagurus hirtimanus from the clade containing the remainder of the species of the genus Pagurus reflects the difference in spermatozoal morphology that exists between this Indo-Pacific species and its European relatives $P$. bernhardus, $P$. chevreuxi and $P$. prideaux (Tudge, 1995a, b). The very speciose genus Pagurus (with over 150 taxa) is a heterogeneous assemblage with, as yet, ill-defined affinities with a rapidly growing number of sister genera. A paraphyletic assemblage Paguridae has been suggested previously by Gore
\& Scotto (1983), McLaughlin (1983b), and Richter \& Scholtz (1994) and is intimated in the present analysis.

Family Parapaguridae. The single investigated parapagurid, Sympagurus sp., lies within the clade containing the members of the family Paguridae in this analysis (Figs. $1 \& 2$ ). The presence of an accessory ampulla (character 29) and, less so, the form of the spermatophore stalk (character 31) link some members of the family Paguridae with the investigated parapagurids. Similarly, the perforatorial chamber shape (character 5), and absence of microvillar projections (character 6) are synapomorphies (Tudge, 1995a, b).

\section{Superfamily Lomoidea}

Family Lomidae. The single representative of this superfamily, Lomis hirta, is considered to have a very primitive spermatozoal morphology that indicates a basal position for this crab within the Anomura (Tudge, 1997). The spermatozoon of Lomis hirta shares many plesiomorphic characters with other decapods (notably the complete embedding in the cytoplasm of the small acrosomal vesicle, the possible nuclear origin of the microtubular arms, and the inconsistent number of microtubular arms). The above characters, combined with an imperfectly known spermatophore morphology, place Lomis at the base of all the investigated decapods, with the exception of the thalassinoids Trypaea and Axius and the palinurids (Figs. 1 \& 2). Previous morphological studies (Pilgrim, 1965; McLaughlin, 1983a, b; Martin \& Abele, 1986) have not agreed on the relationship of Lomis hirta to the other anomurans. Richter \& Scholtz (1994), supporting the view of Pilgrim (1965), have suggested that the Lomidae is the sister group to the Paguroidea.

\section{Superfamily Galatheoidea}

Family Chirostylidae. The chirostylids, Eumunida sternomaculata and Uroptychus sp., are widely placed in the analysis and are more closely associated (spermatologically) with a variety of paguroids than to any galatheoids (Fig. 1). The chirostylids investigated may represent in part a link between these two major superfamilies. Martin \& Abele (1986) previously noted the differ- 
ences between members of the Chirostylidae and other galatheoids.

Family Galatheidae.'Allogalathea elegans and Munida sp. form a small clade at the base of a larger clade containing the pagurids, parapagurids, chirostylids, and the diogenid genus Clibanarius (Figs. 1 \& 2). The third genus investigated in the Galatheidae, Munidopsis (considered a very heterogeneous genus by McLaughlin (1983b)), never grouped with the former two genera and is shown as the sister group to them and to the above-mentioned larger clade. The family Galatheidae did not form a separate monophyletic clade (Figs. 1 \& 2).

Family Porcellanidae. The representatives in this family form a monophyletic group in this analysis (Figs. 1 \& 2). The porcellanid clade comprised two sister clades containing the two representatives in the genus Petrolisthes in one, and the three remaining porcellanid genera, Aliaporcellana, Pisidia and Polyonyx, in the other. This dichotomy, based on spermatological and spermatophore data (Tudge, 1995a, b; Tudge \& Jamieson, 1996a, b), is consistent with larval (Sankolli, 1965; Gore, 1971; Van Dover et al., 1982) and adult somatic morphology (Haig, 1965). The Porcellanidae are depicted as a basal, sister group to the Paguroidea and the remaining galatheoids (Fig. 1, point D), and this dichotomy indicates the point on the tree where the number of microtubular arms changes from the plesiomorphic number of four or more, being fixed at three arms for the remaining terminal taxa.

\section{Superfamily Hippoidea}

Family Hippidae. The single representative of this family and superfamily investigated, Hippa pacifica, is linked to the base of the anomuran clade and paired with the thalassinid Thalassina squamifera (Figs. 1 \& 2). This relationship provides some support for the suggestion that, among the anomurans, the hippoids are the more closely related group to the thalassinoids (Martin \& Abele, 1986). However, caution should be exercised when interpreting the close relationship between Thalassina and Hippa indicated in this analysis as the spermatozoal and spermatophore morphologies of Thalassina squamifera are im- perfectly known (Tudge, 1995a, b). The superfamily Hippoidea usually is considered to be a distinct evolutionary line within the Anomura with its closest links to the Galatheoidea (Makarov, 1962; Scholtz \& Richter, 1995), and independent neurological evidence supports this (Paul, 1989). Spermatologically, Hippa pacifica is distinct from the other anomurans here investigated with certain aspects of its perforatorial chamber (characters $8 \&$ 9) being diagnostic (Fig. 1). Hippa shares the possession of a cytoplasmic origin of the sperm microtubular arms (character 1) with the remainder of the anomuran representatives (with the possible exception of Lomis) (Fig. 1, point B), but it separated from the same representatives by virtue of not developing the pedunculate spermatophore (Fig. 1, point C). Other hippoids are reported to have pedunculate spermatophores (Subramoniam, 1984) and so the addition of further hippoid taxa may change this current result.

There is a lack of comparable studies of anomuran phylogeny in the literature except for the morphological analyses of McLaughlin (1983b) and Martin \& Abele (1986), and at present there are no comparable molecular studies. The papers of Spears \& Abele (1988) and Cunningham et al. (1992) provide molecular data on the relationship of only a few anomuran genera. In general, the phylogenetic analysis presented here, using purely spermatological and spermatophoral evidence, supports most of the results of McLaughlin (1983b) and, less so, Martin \& Abele (1986).

Some agreement with previous morphological and molecular analyses emerges in many areas of the current tree (Figs. 1 and 2). Agreement is seen in the close relationship between the Coenobitidae and the majority of the members in the Diogenidae (McLaughlin, 1983b; Martin \& Abele, 1986; Spears \& Abele, 1988; Cunningham et al., 1992; Richter \& Scholtz, 1994) and a similar relationship between the Paguridae and Parapaguridae (McLaughlin, 1983b; Martin \& Abele, 1986). Interestingly, a close link between the Paguridae (in particular the genus Pagurus) and the Lithodidae (see Makarov, 1962; McLaughlin, 1983b; Cunningham et al., 1992) has been recently supported by new spermatozoal 
and spermatophore evidence by the author (Tudge et al, 1998), but this new data set has yet to be included in any phylogenetic analysis. The essentially basal position of Lomis hirta (Figs. 1 and 2), when compared to the other anomurans, supports the results of McLaughlin (1983b). The distinct position of the Hippoidea (Makarov, 1962; McLaughlin, 1983b; Martin \& Abele, 1986) and the plesiomorphic position of the Thalassinoidea (Martin \& Abele, 1986) are also supported by the current spermatological phylogeny.

However, certain aspects of my analysis disagree with previous phylogenies for the Anomura. This study suggests a closer relationship between the Galatheoidea (in particular the Galatheidae and Chirostylidae) and the Paguroidea than that suggested by McLaughlin (1983b) from morphological evidence. Conflict also occurs with the phylogeny of Martin \& Abele (1986) in their placement of Lomis between the Galatheoidea and Paguroidea, with a much more basal position being suggested here by the spermatological evidence (Figs. 1 and 2). Comparisons with the broader decapod phylogeny of Scholtz \& Richter (1995) are much harder to draw and the spermatological results presented here would appear to simply preclude a close relationship of the Thalassinoidea with the Anomura and Brachyura (their "Meiura").

The current analysis deals with only 9 of the 13 anomuran families, thus it seems obvious that investigation of the spermatozoa and spermatophores of representatives from the missing families (the Aeglidae, Albuneidae, Lithodidae, and Pylochelidae) is required to complete the survey. Similarly, there is a need to sample more representatives from some of the rarer and often poorly sampled families and genera. Some examples include more hippoids, chirostylids, and parapagurids, and species from genera such as Cancellus, Porcellanopagurus, and Xylopagurus. Spermatozoal or spermatophoral autapomorphies for taxa might be confirmed through repetitive sampling of different genera within a family or multiple species within a genus.

Some salient problems in anomuran phylogeny that arise from this analysis will require further attention from researchers using these spermatological or other available techniques. These problems include the validity of the Anomura as a coherent taxon (considering the exhibited differences in placement of groups such as the Hippoidea and Lomoidea), the heterogeneity of the Thalassinoidea, the monophyly of the Galatheoidea (in particular the inclusion of the Porcellanidae), the true affinities of the Chirostylidae, and the divergent placement of the genus Clibanarius from their supposedly nearest diogenid relatives.

An important consideration for future research is that specimens (particularly rare or pivotal taxa) be differentially preserved for different methods of evaluation (spermatological, neurological, molecular) rather than treated to the standard formalin and ethanol fixation for morphological studies. This latter practice (albeit the most common) effectively precludes the use of specimens from the vast museum collections around the world for these alternative research projects, which would otherwise have the capability to provide useful and additional information to resolve phylogenetic questions.

\section{Conclusions}

While recognizing that addition of further taxa may alter some of the groupings obtained, the present analysis, based solely on spermatozoal and spermatophore evidence, indicates that the Anomura and two of its constituent superfamilies, the Paguroidea and Galatheoidea, are not monophyletic assemblages. The infraorders Astacidea and Brachyura appear to be paraphyletic to most of the Anomura. The Anomura (with the possible exception of Lomis) share the unique synapomorphy of having microtubular arms of cytoplasmic origin. The superfamily Thalassinoidea is not a monophyletic taxon (even when they are designated as the outgroup). The only monophyletic anomuran families are the Coenobitidae and Porcellanidae, while the Diogenidae, Paguridae, Chirostylidae, and Galatheidae appear to be paraphyletic. The paguroid families Paguridae and Parapaguridae together form a monophyletic clade with the exception of Porcellanopagurus. 
The two representatives in the family Chirostylidae (Eumunida and Uroptychus) do not group with the other galatheoids investigated. The hippoid Hippa forms the sister group to the remainder of the anomuran taxa (with the exception of Lomis). Lomis occurs as a separate (basal) sister taxon to the remainder of the Anomura and the Astacidea and Brachyura.

\section{Acknowledgments}

The author has benefited from frequent conversations with, and the sound advice of, Prof. Barrie Jamieson (Zoology Dept., The University of Queensland, Australia), Dr. Cliff Cunningham (Zoology Dept., Duke University, USA) and Dr. Rafael Lemaitre (Dept. of Invertebrate Zoology, NMNH, USA). The author also wishes to thank the helpful staff of the Zoology Department, The University of Queensland, Australia where this project had its beginnings and the Department of Invertebrate Zoology, National Museum of Natural History, Smithsonian Institution, Washington D.C., USA, where it was completed. This paper was improved by the suggestions and comments of an anonymous reviewer. During the writing of this paper the author was funded from a Smithsonian Institution Postdoctoral Fellowship (1995-96) and an Australian Research Council Postdoctoral Research Fellowship (1996).

\section{References}

Abele, L.G., 1991. Comparison of morphological and molecular phylogeny of the Decapoda. Mem. Qld. Mus., 31: 101-108.

Abele, L.G., W. Kim \& B.E. Felgenhauer, 1989. Molecular evidence for inclusion of the phylum Pentastomida in the Crustacea. Mol. Biol. Evol, 6: 685-691.

Bauer, R.T., 1986. Phylogenetic trends in sperm transfer and storage complexity in decapod crustaceans. J. crust. Biol., 6: 313-325.

Boas, J.E.V., 1880. Studier over Decapodernes Slaegtskabsforhold. Kong. dansk. Vidensk. Selsk. Skr., Nat.-math.Afd., (Raekke 6) 1: 25-210.

Burkenroad, M.D., 1963. The evolution of the Eucarida (Crustacea, Eumalacostraca) in relation to the fossil record. Tulane Stud. Geol., 2: 3-16.

Burton, T.E., 1995. The spermatid pathway and associated reproductive structures of the squat lobster Thenus orientalis (Lund, 1793). Invert. Reprod. Devel., 28: 5361.

Cunningham, C.W., N.W. Blackstone \& L.W. Buss, 1992. Evolution of king crabs from hermit crab ancestors. $\mathrm{Na}$ ture, 355: 539-542.

Dudenhausen, E.E. \& P. Talbot, 1982. An ultrastructural analysis of mature sperm from the crayfish Pacifastacus leniusculus Dana. Int. J. Invert. Reprod. Devel, 5: 149159.

Dudenhausen, E.E. \& P. Talbot, 1983. An ultrastructural comparison of soft and hardened spermatophores from the crayfish Pacifastacus leniusculus Dana. Can. J. Zool., 61: 182-194.

Ehlers, U., 1985. Phylogenetic relationships within the Platyhelminthes. In: S.C. Morris, J.D. George, R. Gibson \& H.M. Platt (eds.), The origin and relationships of lower invertebrates: 143-158 (Clarendon Press, Oxford).

Forest, J., 1984. Révision du genre Aniculus (Decapoda Diogenidae). Crustaceana, Suppl. 8: 1-91.

Forest, $J_{*}$ 1995. Crustacea Decapoda Anomura: Révision du genre Trizopagurus Forest, 1952 (Diogenidae), avec l'établissement de deux genres nouveaux. In: A. Crosnier (ed.), Résultats des Campagnes MUSORSTOM, 13. Mém. Mus. natn. Hist. nat., 163; 9-149.

Glaessner, M.F., 1969. Decapoda. In: R.C. Moore (ed.), Treatise on invertebrate paleontology, Arthropoda 4. Part R, vol. 2: R399-R533 (Geological Society of America \& University of Kansas Press, Lawrence).

Gore, R.H., 1971. The complete larval development of Porcellana sigsbeiana (Crustacea: Decapoda) under laboratory conditions. Mar. Biol., 11: 344-355.

Gore, R.H. \& L.E. Scotto, 1983. Studies on decapod Crustacea from the Indian River region of Florida XXVII. Phimochirus holthuisi (Provenzano, 1961) (Anomura: Paguridae): The complete larval development under laboratory conditions, and the systematic relationships of its larvae. J. crust. Biol., 3: 93-116.

Guinot, D, 1977. Proposition pour une nouvelle classification des Crustacés Décapodes Brachyoures. C. r. hebd. Séanc. Acad. Scì, Paris, (D) 285: 1049-1052.

Guinot, D., 1978. Príncipes d'une classification évolutive des Crustacés Décapodes Brachyoures. Bull, biol. Fr. Belg*, 112: 211-292.

Gurney, R., 1942. Larvae of decapod Crustacea: 1-306 (Ray Society, London).

Haig, J., 1965. The Porcellanidae (Crustacea, Anomura) of Western Australia with descriptions of four new Australian species. J. Roy. Soc. Western Aust., 48: 97-118.

Healy, J.M., 1988. Sperm morphology and its systematic importance in the Gastropoda. Malacol. Rev., Suppl. 4: 251266.

Healy, J.M. \& B.G.M. Jamieson, 1992. Ultrastructure of the spermatozoon of the tuatara (Sphenodon punctatus) and its relevance to the relationships of the Sphenodontida. Phil. Trans. Roy. Soc. London, (B) 335: 193-205.

Hillis, D.M., 1991. Discriminating between phylogenetic sìgnal and random noise in DNA sequences. In: M.M. Miyamoto \& J. Cracraft (eds.), Phylogenetic analysis of DNA sequences: 278-294 (Oxford Univ. Press, New York).

Hillis, D.M. \& J.P. Huelsenbeck, 1992. Signal, noise, and reliability in molecular phylogenetic analyses. J. Hered. 83: 189-195.

Jamieson, B.G.M., 1981. The ultrastructure of the Oligochaeta: 1-462 (Academic Press, New York). 
Jamieson, B.G.M., 1983. Spermatozoal ultrastructure: evolution and congruence with a holomorphological phylogeny of the Oligochaeta (Annelida), Zoologica Scr., 12: 107114.

Jamieson, B.G.M., 1987. The ultrastructure and phylogeny of insect spermatozoa: 1-320 (Cambridge Univ. Press, Cambridge).

Jamieson, B.G.M., 1989. Ultrastructural comparison of the spermatozoa of Ranina ranina (Oxystomata) and of Portunus pelagicus (Brachygnatha) (Crustacea, Brachyura). Zoomorphology, 109: 103-111.

Jamieson, B.G.M., 1991a. Ultrastructure and phylogeny of crustacean spermatozoa. Mem. Qld. Mus., 31: 109-142.

Jamieson, B.G.M., 1991b. Fish evolution and systematics: evidence from spermatozoa: 1-319 (Cambridge Univ. Press, Cambridge).

Jamieson, B.G.M., 1993. Spermatological evidence for the taxonomic status of Trapezia (Crustacea: Brachyura: Heterotremata). Mem. Qld. Mus., 33: 225-234.

Jamieson, B.G.M., 1994. Phylogeny of the Brachyura with particular reference to the Podotremata: evidence from a review of spermatozoal ultrastructure (Crustacea, Decapoda). Phil. Trans, Roy. Soc. London, (B) 345: 373393.

Jamieson, B.G.M., 1995a. Evolution of tetrapod spermatozoa with particular reference to amniotes. In: B.G.M. Jamieson, J. Ausio \& J.-L. Justine (eds.), Advances in spermatozoal phylogeny and taxonomy. Mém. Mus. natn. Hist. nat., Paris, 166: 343-358.

Jamieson, B.G.M., 1995b. The ultrastructure of spermatozoa of the Squamata (Reptilia) with phylogenetic considerations. In: B.G.M. Jamieson, J. Ausio \& J.-L, Justine (eds.), Advances in spermatozoal phylogeny and taxonomy. Mếm. Mus, natn. Hist. nat., Paris, 166: 359-383.

Jamieson, B.G.M. \& H.J. Grier, 1993. Influences of phylogenetic position and fertilization biology on spermatozoal ultrastructure exemplified by exocoetoid and poeciliid fish. Hydrobiologia, 271: 11-25.

Jamieson, B.G.M. \& J.M. Healy, 1992. The phylogenetic position of the tuatara, Sphenodon (Sphenodontida, Amniota) as indicated by a cladistic analysis of the ultrastructure of spermatozoa. Phil. Trans. Roy. Soc. London, (B) 335: 207-219.

Jamieson, B.G.M. \& G.W. Rouse, 1989. The spermatozoa of the Polychaeta (Annelida): an ultrastructural review. Biol. Rev, 64: 93-157.

Jamieson, B.G.M. \& C.C. Tudge, 1990. Dorippids are Heterotremata: evidence from ultrastructure of the spermatozoa of Neodorippe astuta (Dorippidae) and Portunus pelagicus (Portunidae) (Brachyura: Decapoda). Mar. Biol, 106: 347-354.

Jamieson, B.G.M., C. Erséus \& M. Ferraguti, 1987. Parsimony analysis of the phylogeny of some Oligochaeta (Annelida) using spermatozoal ultrastructure. Cladistics, 3: 141-155.

Jamieson, B.G.M., D. Guinot \& B. Richer de Forges, 1995. Phylogeny of the Brachyura (Crustacea, Decapoda): evidence from spermatozoal ultrastructure. In: B.G.M. Jamieson, J. Ausio \& J.-L. Justine (eds.), Advances in spermatozoal phylogeny and taxonomy. Mém. Mus. natn. Hist. nat., Paris, 166: 265-283.

Justine, J.-L, 1991. Phylogeny of parasitic Platyhelminthes: a critical study of synapomorphies proposed on the basis of the ultrastructure of spermiogenesis and spermatozoa. Can. J. Zool, 69: 1421-1440.

Källersjö, M,, J.S. Farrì, A.G. Kluge \& C. Bult, 1992. Skewness and permutation. Cladistics, 8: 275-287.

Kim, W. \& L.G. Abele, 1990. Molecular phylogeny of selected decapod crustaceans based on 18s rRNA nucleotide sequences. J. crust. Biol, 10: 1-13.

Koltzoff, N.K, 1906. Studien über die Gestalt der Zelle. I. Untersuchungen über die Spermien der Decapoden, als Einleitung in das Problem der Zellengestalt. Arch. mikrosk. Anat., 67: 364-572.

MacDonald, J.D., R.B. Pike \& D.I. Williamson, 1957. Larvae of the British species of Diogenes, Pagurus, Anapagurus and Lithodes (Crustacea, Decapoda). Proc. zool. Soc. London, 128: 209-257.

Maddison, W.P. \& D.R. Maddison, 1992. MacClade (Version 3). Analysis of phylogeny and character evolution (Sinauer Associates, Inc. Sunderland, Massachusetts, U.S.A).

Makarov, V.V., 1962. Fauna of U.S.S.R. Crustacea vol. 10 (3), Anomura: 1-283 (Israel Program for Scientific Translations, Jerusalem) (English translation of Makarov, 1938).

Martin, J.W. \& L.G. Abele, 1986. Phylogenetic relationships of the genus Aegla (Decapoda: Anomura: Aeglidae), with comments on anomuran phylogeny. J. crust. Biol, 6: 576616.

Mattei, X., 1991. Spermatozoon structure and its systematic implications in fishes. Can. J. Zool, 69: 3038-3055.

Matthews, D.C., 1956. The origin of the spermatophoric mass of the sand crab, Hippa pacifica. Q. J. microsc. Sci., 97: 257-268.

McLaughlin, P.A., 1983a. A review of the phylogenetic position of the Lomidae (Crustacea: Decapoda: Anomala). J. crust. Biol, 3: 431-437.

McLaughlin, P.A., 1983b. Hermit crabs - are they really polyphyletie? J. crust. Biol, 3: 608-621.

McLaughlin, P.A. \& L.B. Holthuis, 1985. Anomura versus Anomala. Crustaceana, 49: 204-209.

Mouchet, S., 1931. Spermatophores des Crustacés Décapodes Anomoures et Brachyoures et castration parasitaire chez quelques Pagures. Annls. Stat. océanogr. Salammbô, 6: 1-203.

Paul, D.H, 1989. A neurophylogenist's view of decapod Crustacea. Bull. mar. Sci., 45: 487-504.

Pilgrim, R.L.C., 1965. Some features in the morphology of Lomis hirta (Lamarck) (Crustacea: Decapoda) and a discussion of its systematic position and phylogeny. Aust. J. Zool, 13: 545-557.

Poore, G.C.B., 1994, A phylogeny of the families of Thalassinidea (Crustacea: Decapoda) with keys to families and genera. Mem. Mus. Vict, 54: 79-120.

Retzius, G., 1909. Die Spermien der Crustaceen. Biologische Unters., 14: 1-54.

Richter, S. \& G. Scholtz, 1994. Morphological evidence for 
a hermit crab ancestry of lithodids (Crustacea, Decapoda, Anomala, Paguroidea). Zool. Anz, 233: 187-210.

Saint Laurent, M. de, 1973. 'Sur la systématique et la phylogénie des Thalassininidea: définition des familles des Callianassidae et des Upogebiidae et diagnose de cinq genres nouveaux (Crustacea Decapoda), C. r. hebd. Séanc. Acad. Sci., Paris, (D) 277: 513-516.

Sankolli, K.N., 1965. Studies on larval development in Anomura (Crustacea, Decapoda) - I. Proceedings of the Symposium on Crustacea. Held at Emakulam (January 12-15, 1965), Part II: 744-775 (Marine Biological Association of India; Bangalore Press, Bangalore).

Scholtz, G. \& S. Richter, 1995. Phylogenetic systematics of the reptantian Decapoda (Crustacea, Malacostraca). Zool. J. Linn. Soc., 113: 289-328.

Spears, T. \& L.G. Abele, 1988. Phylogenetic relationships of crustacean anomurans based on partial 18s rRNA nucleotide sequences. Am. Zool, 29: 25A.

Spears, T., L.G. Abele \& W. Kim, 1992. The monophyly of brachyuran crabs: A phylogenetic study based on 18S rRNA. Syst. Biol, 41: 446-461.

Storch, V. \& B.G.M. Jamieson, 1992. Further spermatological evidence for including the Pentastomida (tongue worms) in the Crustacea. Int. J. Parasit, 22: 95-108.

Subramoniam, T., 1984. Spermatophore formation in two intertidal crabs Albunea symnista and Emerita asiatica (Decapoda: Anomura). Biol. Bull., 166: 78-95.

Swofford, D.L., 1993. PAUP: Phylogenetic analysis using parsimony, version 3.1.1 (computer program distributed by the Illinois Natural History Survey, Champaign, Illinois, U.S.A).

Talbot, P. \& P. Chanmanon, 1980a. The structure of sperm from the lobster, Homarus americanus. J, Ultrastruct. Res., 70: 275-286.

Talbot, P. \& P. Chanmanon, 1980b. Morphological features of the acrosome reaction of Lobster (Homarus) sperm and the role of the reaction in generating forward sperm movement. J. Ultrastruct. Res., 70: 287-297.

Talbot, P. \& R.G. Summers, 1978. The structure of sperm from Panulirus, the spiny lobster, with special regard to the acrosome. J. Ultrastruct. Res., 64: 341-351.

Tam, Y.K., I. Kornfield \& F.P. Ojeda, 1996. Divergence and zoogeography of mole crabs, Emerita spp. (Decapoda: Hippidae), in the Americas. Mar. Biol, 125: 489-497.

Tudge, C.C., 1991. Spermatophore diversity within and among the hermit crab families, Coenobitidae, Diogenidae, and Paguridae (Paguroidea, Anomura, Decapoda). Biol. Bull., 181: 238-247.

Tudge, C.C., 1992. Comparative ultrastructure of hermit crab spermatozoa (Decapoda: Anomura: Paguroidea). J. crust. Biol., 12: 397-409.

Tudge, C.C., 1995a. The ultrastructure and phylogeny of anomuran crab spermatozoa: 1-346 (Ph.D. Thesis, Zoology Department, The University of Queensland, Brisbane, Australia).

Tudge, C.C., 1995b. Ultrastructure and phylogeny of the spermatozoa of the infraorders Thalassinidea and Anomura (Decapoda, Crustacea). In: B.G.M. Jamieson, J.
Ausio \& J.-L. Justine (eds.), Advances in spermatozoal phylogeny and taxonomy. Mém. Mus. natn. Hist. nat, Paris, 166: 251-263.

Tudge, C.C., 1996. Spermatophore morphology and spermatozoal ultrastructure of the recently described hermit crab, Strigopagurus boreonotus Forest, 1995 (Decapoda, Anomura, Diogenidae), Bull. Mus. natn. Hist. nat., Paris, 18 (3-4): 251-259.

Tudge, C.C., 1997. Spermatological evidence supports the taxonomic placement of the Australian endemic hairy stone crab, Lomis hirta (Decapoda, Anomura, Lomidae). Mem. Mus. Vict., 56(1): 235-244.

Tudge, C.C. \& B.G.M. Jamieson, 1991. Ultrastructure of the mature spermatozoon of the coconut crab Birgus latro (L.) (Coenobitidae, Paguroidea, Decapoda). Mar. Biol., 108: 395-402.

Tudge, C.C. \& B.G.M. Jamieson, 1996a. Spermatophore and spermatozoal morphology in the Porcellanidae. I. Aliaporcellana suluensis and Pisidia longicornis (Decapoda, Anomura, Porcellanidae). Crust. Res., 25: 1-14.

Tudge, C.C. \& B.G.M. Jamieson, 1996b. Spermatophore and spermatozoal morphology in the Porcellanidae. II. The genera Petrolisthes and Polyonyx (Decapoda, Anomura, Porcellanidae). J. crust. Biol., 16(3): 535-546.

Tudge, C.C., B.G.M. Jamieson, L. Sandberg \& C. Erséus, 1998. Ultrastructure of the mature spermatozoon of the King Crab Lithodes maja (L.) (Lithodidae, Anomura, Decapoda): Further confirmation of a lithodid-pagurid relationship. Invertebrate Biology, 117(1) (in press).

Van Dover, C.L., J.R. Factor \& R.H. Gore, 1982. Developmental patterns of larval scaphognathites: an aid to the classification of anomuran and brachyuran Crustacea. $\mathbf{J}$. crust. Biol., 2: 48-53.

Vaughn, J.C. \& F.J. Traeger, 1976. Conservation of repeated DNA base sequences in the Crustacea: A molecular approach to decapod phylogeny. J. mol. Evol, 7: 111-131.

Wielgus, E., 1973. The phylogenetic significance of spermatozoa in Decapoda. Przegl. Zool, 17: 420-426.

Wingstrand, K.G., 1972. Comparative spermatology of a pentastomid, Raillietiella hemidactyli, and a branchiuran crustacean, Argulus foliaceus, with a discussion of pentastomid relationshipps. Kong. dansk. Vidensk. Selsk. biol. Skrift., 19(4): 1-72, pls. 1-23.

Received: 5 July 1996

\section{Appendix A. Spermatozoal characters}

1. Origin of microtubular arms. The bundles of microtubules, representing the bases of the microtubular arms, can be either nuclear in origin, or develop and emerge from the cytoplasm. The hairy stone crab Lomis hirta has microtubules in both the nucleus and the cytoplasm but because spermiogenesis has not been studied their origin remains equivocal. The brachyuran crabs do not possess microtubular arms and so the character has been scored as 
secondarily absent. (Nuclear origin $=0$, cytoplasmic orígin $=1$, secondarily absent $=2$.)

2. Number of microtubular arms. The number of microtubular arms in the mature spermatozoa of the thalassinoids, porcellanids, and hippoids is four or more while representatives from the Paguroidea and Galatheoidea (with the exception of the Porcellanidae) always have only three. The exact number of microtubular arms is not known for Thalassina squamifera, Lomis hirta, and Pisidia longicornis, As above, this character has been scored as secondarily absent in Portumus pelagicus. (More than 3 arms $=0,3$ arms $=1$, secondarily absent $=2$.)

3. Proportion of the acrosome vesicle that the cytoplasm envelops. The acrosomal vesicle may be totally embedded in the cytoplasm (except for the opercular region), significantly embedded, or the acrosomal vesicle may be superior to the cytoplasm with only its most posterior portion embedded. (All of the acrosomal vesicle embedded [except operculum] $=0$, half or more than half of the acrosomal vesicle embedded $=1$, posterior portion only embedded $=2$.)

4. Presence and extent of perforatorial chamber. A distinct perforatorial chamber appears to be absent in the spermatozoa of Trypaea australiensis, Panulirus argus, and Thenus orientalis but present in the remaining species studied. In the species with a perforatorial chamber, this structure can extend from the base of the acrosome vesicle to a subterminal position below the operculum (postequatorial) or terminate at or below the mid-point of the acrosome vesicle (pre-equatorial). (Perforatorial chamber absent $=0$, post-equatorial $=1$, pre-equatorial $=2$.)

5. Perforatorial chamber shape. For those species with a perforatorial chamber, it can assume one of three forms: (1) a bulbous posterior section with a thin, tapering anterior projection, (2) a columnar or basically uniform cylindrical perforatorial chamber, or (3) entirely bulbous or having the anterior region swollen into a bulbous area. (Perforatorial chamber absent $=0$, perforatorial chamber bulbous posteriorly and tapering anteriorly $=1$, columnar or cylindrical $=2$, entirely bulbous or bulbous anteriorly = 3.)

6. Presence and form of microvillar projections. Microvillar projections are small finger-like structures that extend laterally from the perforatorial chamber wall into the posterior region of the perforatorial chamber in some anomuran representatives. When the mícrovillar projections are present, they are either short and tuberculous or longer and filamentous. (Microvillar projections absent $=0$, short and tuberculous $=1$, long and filamentous $=2$.)

7. Ornamentation of perforatorial chamber walls. The walls of the perforatorial chamber (if one is present) may or may not be ornamented with longitudinal grooves or septa. (Perforatorial chamber absent $=0$, perforatorial chamber walls smooth $=1$, shallow longitudinal corrugations $=2$, prominent longitudinal septa $=3$.)

8. Form of the anterior tip of the perforatorial chamber. In the majority of species the anterior end or apex of the perforatorial chamber (if one is present) is entire but in representatives from the genus Calcinus and the hippid,
Hippa pacifica, the perforatorial chamber divaricates into two or more perforatorial points or fingers. (Perforatorial chamber absent $=0$, anterior end of perforatorial chamber entire $=1$, separated into two or more points or fingers $=$ 2.)

9. Perforatorial chamber contents. Where one is present, the perforatorial chamber in the majority of taxa does not contain any structures but has a homogeneous or heterogeneous granular matrix. Exceptions are the presence of tortuous perforatorial tubules or a longitudinal septum which "hangs" inside the chamber. (Perforatorial chamber absent $=0$, perforatorial chamber contents without tubules or septum $=1$, prominent tubules $=2$, prominent dividing septum $=3$.)

10. Acrosome vesicle dimensions. The acrosome vesicle shapes exhibited by the various taxa are arranged into four categories. (1) Subspheroidal acrosome with length to width ratios less than 1.0. (2) Spherical to ovoid acrosome, encompassing the acrosome length to width ratios of 1.01.5. (3) Ovoid to oblong-ovoid acrosome with length to width ratios of 1,6-2.5. (4) Oblong-ovoid to elongate cylindrical acrosome with length to width ratios of 2.65.0. (Acrosomal vesicle length to width ratios $<1.0=0$, $1.0-1.5=1,1.6-2.5=2,2.6-5.0=3$.)

11. Acrosome vesicle contents. The spermatozoa of Axius glyptocercus, Trypaea australiensis, Panulirus "argus, Thenus orientalis, and less so Lomis hirta exhibit no concentric zonation of the acrosome vesicle contents, while the remaining taxa show distinct concentric zonation. (Concentric zonation absent $=0$, present $=1$ )

12. Operculum form. The electron-dense operculum may be centrally perforate or entire. In Lomis hirta there is more than one perforation and the operculum appears interrupted. The condition of the operculum is unknown in Thenus orientalis. (Operculum imperforate $=0$, perforate =1.)

13. Thickened ring. The brachyuran crabs have a dense ring at the posterior end of the acrosome vesicle surrounding the perforatorial chamber base (see Jamieson, 1991a). A dense ring of similar appearance is present in the same position in the spermatozoa of Thalassina squamifera. (Thickened ring absent $=0$, present $=1$.)

14. Acrosome ray zone. The acrosome ray zone is a modified zone within the acrosome vesicle that has the appearance, in transverse section, of dark and light radiating bands. This zone may occupy the majority of the acrosome vesicle contents or may be smaller in extent. Some taxa (Calcinus laevimanus, Cancellus sp., and Pagurus prideaux) have a similar-looking zone but the homology is uncertain. (Acrosome ray zone absent $=0$, present $=1$ )

15. Subopercular zone. The subopercular zone (when present) is an homogeneous, coarsely granular region that is directly below or often fills the concavity of the operculum and may extend for some distance down the acrosome vesicle. This zone may be divided into two or more separate regions. (Subopercular zone absent $=0$, entire $=$ 1 , divided into two or more regions $=2$, divided into three or more regions $=3$.)

16. Dense perforatorial ring. The dense perforatorial ring is 
an electron-dense zone that occurs around the posterior bulbous region of the perforatorial chamber in the representatives of the genus 'Clibanarius only. (Dense perforatorial ring absent $=0$, present $=1$.)

17. Fibrillar acrosome core. The fibrillar acrosome core is the anterior modification of the inner acrosome zone in the spermatozoa of Diogenes custos and D. pallescens into an elongate fibrillar structure which spirals apically. (Fibrillar acrosome core absent $=0$, present $=1$.)

18. Reticulated acrosome zones. The reticulated acrosome zones are one or more concentric zones, towards the centre of the acrosome vesicle, which have a reticulated appearance in both transverse and longitudinal section. They are found in most studied representatives of the families Paguridae and Parapaguridae. (Reticulated acrosome zones absent = 0 , present $=1$.)

19. Lacunar sheath. The lacunar sheath or vesiculated sheath has been observed in the spermatozoa of the pagurid Porcellanopagurus sp. and is a thin, vesiculated or faintly loculated cylinder that tightly surrounds the perforatorial chamber at the midpoint of the acrosome vesicle. (Lacunar sheath absent $=0$, present $=1$ )

20. Position of microtubular arms. Where they are present, the microtubular arms emerge from the cytoplasm surrounding the acrosome vesicle at the posterior end of the acrosome vesicle in nearly all taxa investigated, except for Xylopagurus sp., where they emerge in an anterior position. (Microtubular arms posteriorly situated $=0$, anteriorly situated $=1$, secondarily absent $=2$.)

21. Inner acrosome zone. The inner acrosome zone, when present, is generally the innermost zone of the concentric series and is homogeneous, finely granular and of moderate electron density. The zone may be divided into two distinct regions. The imperfect fixation of Thalassina squamifera does not allow a decision to be made concerning the presence or form of an inner acrosome zone. (Inner acrosome zone absent $=0$, entire $=1$, divided $=2$.)

22. Microtubular core. The microtubular core is the large bundle of longitudinally arranged microtubules that occupy the central axis of the elongate spermatozoa in the porcellanid species Aliaporcellana suluensis, Písidia longicornis, and Polyonyx transversus. (Microtubular core absent $=0$, present $=1$.)

23. Dense perforatorial cone. The dense perforatorial cone occurs as an electron-dense, thin layer enveloping the anterior region of the perforatorial chamber in the porcellanids and, questionably, the pagurid Porcellanopagurus sp. It is usually separated from the perforatorial chamber by a thin layer of inner acrosome zone, is perforate at the perforatorial chamber apex, and may "extend to the base of the perforatorial chamber. (Dense perforatorial cone absent $=0$, present $=1$.)

24. Posterior perforatorial ring. The posterior perforatorial ring is present only in the investigated members of the family Porcellanidae where it occurs as a dense ring around the perforatorial chamber in the posterior region of the acrosome vesicle. (Posterior perforatorial ring absent = 0 , present $=1$.)
25. Opercular ridge. The opercular ridge is a lateral extension on the external surface of the electron-dense operculum in the two investigated species of the genus Petrolisthes: (Opercular ridge absent $=0$, present $=1$.)

26. Tubular ring. The tubular ring is a structure fourd in the acrosome vesicle of Petrolisthes armatus and $P$. lamarckii. It encircles the perforatorial chamber at the mid-point of the acrosome vesicle and is very electron-dense, but has somewhat paler electron-lucent tubules running concentrically through it. (Tubular ring absent $=0$, present $=1$.)

\section{Spermatophore characters}

27. Spermatophore form. The spermatophores in the taxa investigated can assume one of three forms. (1) A tubular spermatophore extruded in the size and shape of the vas deferens. (2) A pedunculate, tripartite spermatophore consisting of an ampulla attached to a pedestal or base by a stalk of variable length. (3) A spherical to ovoid capsular spermatophore. In Axius glyptocercus, Thalassina squamifera, Eumunida sternomaculata, and Polyonyx transversus the spermatophore morphology is unknown. (Spermatophores tubular $=0$, pedunculate $=1$, capsular $=2$.)

28. Spermatophore ridge. The spermatophore ridge is a raised and thickened area of the spermatophore wall where the two halves of the ampulla split to release the contained spermatozoa. The centre of the spermatophore ridge has a break in the spermatophore wall structure. (Spermatophore ridge absent $=0$, present $=1$.)

29. Presence of accessory ampullae. The spermatophores of the investigated members of the genus Pagurus (with the possible exception of $P$. chevreuxi) and the parapagurid Sympagurus sp. have a smaller accessory ampulla present at the base of the main ampulla. An accessory ampulla may also be present in the chirostylid Uroptychus sp. (Spermatophores with accessory ampulla and main ampulla $=\mathbf{0}$, main ampulla only $=1$.)

30. Presence of tubular extension. The spermatophores of Petrolisthes lamarckii and $P$. armatus have a long tubular extension projecting from the distal end of the ampulla. (Spermatophore ampulla without tubular extension $=\mathbf{0}$, with tubular extension $=1$.)

31. Form of stalk in pedunculate spermatophores. In the taxa which possess pedunculate spermatophores the stalk can assume one of three forms. (1) An extremely short, almost non-existent, pseudo-stalk. (2) A short, thick stalk. (3) A long, thin stalk. (Spermatophores tubular or capsular $=0$, spermatophores pedunculate with small pseudo-stalk $=1$, pedunculate with short, thick stalk $=2$, pedunculate with long, thin stalk = 3.)

32. Spermatophore wall ultrastructure. Where the ultrastructure of the spermatophore wall is known, three distinct forms occur. The spermatophore wall can be (1) homogeneously granular in appearance, (2) heterogeneously granular, or (3) fibrillar. (Spermatophore wall ultrastructure homogeneously granular $=0$, heterogeneously granular $=1$, fibrillar $=2$.) 
Appendix B. Data matrix $\left(\frac{0}{1}=0 / 1\right.$ or an equivocal character state assignment)

Character no.

$\begin{array}{lllllllllllllllllllllll}1 & 1 & 1 & 1 & 1 & 1 & 1 & 1 & 1 & 1 & 2 & 2 & 2 & 2 & 2 & 2 & 2 & 2 & 2 & 2 & 3 & 3 & 3\end{array}$

Taxon

Axius glyptocercus
Trypaea australiensis
Thalassina squamifera
Birgus latro
Coenobita brevimanus
Coenobita perlatus
Coenobita purpureus
Coenobita rugosus
Coenobita variabilis
Calcinus gaimardii
Calcinus laevimanus

Calcinus minutus

Cancellus sp.

Clibanarius corallinus Clibanarius erythropus Clibanarius longitarsus Clibanarius taeniatus Clibanarius virescens Dardanus arrosor Dardanus crassimanus Dardanus lagopodes Dardanus scutellatus Dardanus sp. nov. Diogenes custos Diogenes pallescens Strigopagurus boreonotus

Pagurus bernhardus

Pagurus chevreuxi

Pagurus hirtimanus

Pagurus prideaux

Porcellanopagurus sp.

Xylopagurus sp. nov. Sympagurus sp.

Lomis hirta

Eumunida sternomaculato Uroptychus sp.

Allogalathea elegans

Munida sp.

Munidopsis sp. $\begin{array}{llllllllllllllllllllllllllllllll}0 & 0 & 0 & 1 & 2 & 0 & 3 & 1 & 1 & 3 & 0 & 1 & 0 & 0 & 0 & 0 & 0 & 0 & 0 & 0 & 0 & 0 & 0 & 0 & 0 & 0 & ? & ? & ? & ? & ? & ?\end{array}$ $\begin{array}{llllllllllllllllllllllllllllllll}0 & 0 & 0 & 0 & 0 & 0 & 0 & 0 & 0 & 0 & 0 & 0 & 0 & 0 & 0 & 0 & 0 & 0 & 0 & 0 & 0 & 0 & 0 & 0 & 0 & 0 & 2 & 0 & 1 & 0 & 0 & \text { ? }\end{array}$ $\begin{array}{llllllllllllllllllllllllllllllll}0 & ? & 2 & 1 & 2 & 0 & 1 & 1 & 1 & 1 & 1 & 0 & \underline{0} & 0 & 0 & 0 & 0 & 0 & 0 & 0 & ? & 0 & 0 & 0 & 0 & 0 & ? & ? & ? & ? & ? & \text { ? }\end{array}$ 1

$\begin{array}{llllllllllllllllllllllllllllllll}1 & 1 & 2 & 2 & 2 & 2 & 1 & 1 & 1 & 2 & 1 & 0 & 0 & 1 & 2 & 0 & 0 & 0 & 0 & 0 & 1 & 0 & 0 & 0 & 0 & 0 & 1 & 1 & 1 & 0 & 2 & 2\end{array}$ $\begin{array}{llllllllllllllllllllllllllllllll}1 & 1 & 2 & 2 & 2 & 2 & 1 & 1 & 1 & 3 & 1 & 0 & 0 & 1 & 2 & 0 & 0 & 0 & 0 & 0 & 1 & 0 & 0 & 0 & 0 & 0 & 1 & 1 & 1 & 0 & 2 & 2\end{array}$ $\begin{array}{llllllllllllllllllllllllllllllll}1 & 1 & 2 & 2 & 2 & 2 & 1 & 1 & 1 & 3 & 1 & 0 & 0 & 1 & 2 & 0 & 0 & 0 & 0 & 0 & 1 & 0 & 0 & 0 & 0 & 0 & 1 & 1 & 1 & 0 & 2 & 2\end{array}$ $\begin{array}{llllllllllllllllllllllllllllllll}1 & 1 & 2 & 2 & 2 & 2 & 1 & 1 & 1 & 3 & 1 & 0 & 0 & 1 & 2 & 0 & 0 & 0 & 0 & 0 & 1 & 0 & 0 & 0 & 0 & 0 & 1 & 1 & 1 & 0 & 2 & 2\end{array}$ $\begin{array}{llllllllllllllllllllllllllllllll}1 & 1 & 2 & 2 & 2 & 2 & 1 & 1 & 1 & 3 & 1 & 0 & 0 & 1 & 2 & 0 & 0 & 0 & 0 & 0 & 1 & 0 & 0 & 0 & 0 & 0 & 1 & 1 & 1 & 0 & 2 & 2\end{array}$ $\begin{array}{llllllllllllllllllllllllllllllll}1 & 1 & 2 & 2 & 2 & 2 & 1 & 1 & 1 & 3 & 1 & 0 & 0 & 1 & 2 & 0 & 0 & 0 & 0 & 0 & 1 & 0 & 0 & 0 & 0 & 0 & 1 & 1 & 1 & 0 & 2 & 2\end{array}$ $\begin{array}{llllllllllllllllllllllllllllllll}1 & 1 & 2 & 1 & 3 & 2 & 1 & 2 & 1 & 1 & 1 & 0 & 0 & 0 & 1 & 0 & 0 & 0 & 0 & 0 & 1 & 0 & 0 & 0 & 0 & 0 & 1 & 1 & 1 & 0 & 3 & 2\end{array}$ $\begin{array}{llllllllllllllllllllllllllllllll}1 & 1 & 2 & 1 & 3 & 1 & 1 & 2 & 1 & 1 & 1 & 0 & 0 & 0 & 1 & 0 & 0 & 0 & 0 & 0 & 1 & 0 & 0 & 0 & 0 & 0 & 1 & 1 & 1 & 0 & 3 & 2\end{array}$ $\begin{array}{llllllllllllllllllllllllllllllll}1 & 1 & 2 & 1 & 3 & 1 & 1 & 2 & 2 & 1 & 1 & 0 & 0 & 0 & 1 & 0 & 0 & 0 & 0 & 0 & 1 & 0 & 0 & 0 & 0 & 0 & 1 & 1 & 1 & 0 & 3 & 2\end{array}$ $\begin{array}{llllllllllllllllllllllllllllllll}1 & 1 & 2 & 1 & 1 & 0 & 1 & 1 & 2 & 2 & 1 & 1 & 0 & 0 & 1 & 0 & 0 & 0 & 0 & 0 & 2 & 0 & 0 & 0 & 0 & 0 & 1 & 1 & 1 & 0 & 2 & 2\end{array}$ $\begin{array}{llllllllllllllllllllllllllllllll}1 & 1 & 1 & 1 & 1 & 1 & 1 & 1 & 1 & 1 & 1 & 0 & 0 & 0 & 0 & 1 & 0 & 0 & 0 & 0 & 1 & 0 & 0 & 0 & 0 & 0 & 1 & 1 & 1 & 0 & 3 & 1\end{array}$ $\begin{array}{llllllllllllllllllllllllllllllll}1 & 1 & 1 & 1 & 1 & 1 & 1 & 1 & 1 & 1 & 1 & 0 & 0 & 0 & 1 & 1 & 0 & 0 & 0 & 0 & 1 & 0 & 0 & 0 & 0 & 0 & 1 & 1 & 1 & 0 & 3 & 1\end{array}$ $\begin{array}{llllllllllllllllllllllllllllllll}1 & 1 & 1 & 1 & 1 & 2 & 1 & 1 & 1 & 1 & 1 & 0 & 0 & 0 & 0 & 1 & 0 & 0 & 0 & 0 & 1 & 0 & 0 & 0 & 0 & 0 & 1 & 1 & 1 & 0 & 1 & 1\end{array}$ $\begin{array}{llllllllllllllllllllllllllllllll}1 & 1 & 1 & 1 & 1 & 1 & 1 & 1 & 1 & 1 & 1 & 0 & 0 & 0 & 0 & 1 & 0 & 0 & 0 & 0 & 1 & 0 & 0 & 0 & 0 & 0 & 1 & 1 & 1 & 0 & 3 & 1\end{array}$ $\begin{array}{lllllllllllllllllllllllllllllllll}1 & 1 & 1 & 1 & 1 & 1 & 1 & 1 & 1 & 1 & 1 & 0 & 0 & 0 & 0 & 1 & 0 & 0 & 0 & 0 & 1 & 0 & 0 & 0 & 0 & 0 & 1 & 1 & 1 & 0 & 3 & 1\end{array}$ $\begin{array}{lllllllllllllllllllllllllllllllll}1 & 1 & 2 & 2 & 2 & 1 & 1 & 1 & 1 & 2 & 1 & 0 & 0 & 1 & 1 & 0 & 0 & 0 & 0 & 0 & 1 & 0 & 0 & 0 & 0 & 0 & 1 & 1 & 1 & 0 & 3 & 2\end{array}$ $\begin{array}{llllllllllllllllllllllllllllllll}1 & 1 & 2 & 2 & 2 & 1 & 1 & 1 & 1 & 1 & 1 & 0 & 0 & 1 & 1 & 0 & 0 & 0 & 0 & 0 & 1 & 0 & 0 & 0 & 0 & 0 & 1 & 1 & 1 & 0 & 3 & 2\end{array}$ $\begin{array}{llllllllllllllllllllllllllllllll}1 & 1 & 2 & 2 & 2 & 1 & 1 & 1 & 1 & 2 & 1 & 0 & 0 & 1 & 1 & 0 & 0 & 0 & 0 & 0 & 1 & 0 & 0 & 0 & 0 & 0 & 1 & 1 & 1 & 0 & 3 & 2\end{array}$ $\begin{array}{llllllllllllllllllllllllllllllll}1 & 1 & 2 & 1 & 2 & 2 & 1 & 1 & 1 & 2 & 1 & 0 & 0 & 1 & 1 & 0 & 0 & 0 & 0 & 0 & 1 & 0 & 0 & 0 & 0 & 0 & 1 & 1 & 1 & 0 & 3 & 2\end{array}$ $\begin{array}{llllllllllllllllllllllllllllllll}1 & 1 & 2 & 1 & 2 & 2 & 1 & 1 & 1 & 2 & 1 & 0 & 0 & 1 & 1 & 0 & 0 & 0 & 0 & 0 & 1 & 0 & 0 & 0 & 0 & 0 & 1 & 1 & 1 & 0 & 3 & 2\end{array}$ $\begin{array}{lllllllllllllllllllllllllllllllll}1 & 1 & 2 & 2 & 1 & 2 & 1 & 1 & 1 & 3 & 1 & 0 & 0 & 1 & 1 & 0 & 1 & 0 & 0 & 0 & 2 & 0 & 0 & 0 & 0 & 0 & 1 & 1 & 1 & 0 & 3 & 2\end{array}$ $\begin{array}{llllllllllllllllllllllllllllllll}1 & 1 & 2 & 1 & 1 & 2 & 1 & 1 & 1 & 3 & 1 & 0 & 0 & 1 & 1 & 0 & 1 & 0 & 0 & 0 & 2 & 0 & 0 & 0 & 0 & 0 & 1 & 1 & 1 & 0 & 3 & 2\end{array}$ $\begin{array}{llllllllllllllllllllllllllllllll}1 & 1 & 1 & 1 & 3 & 2 & 1 & 1 & 1 & 1 & 1 & 0 & 0 & 0 & 2 & 0 & 0 & 0 & 0 & 0 & 1 & 0 & 0 & 0 & 0 & 0 & 1 & 1 & 1 & 0 & 3 & 2\end{array}$

$\begin{array}{llllllllllllllllllllllllllllllll}1 & 1 & 1 & 1 & 1 & 0 & 2 & 1 & 1 & 1 & 1 & 0 & 0 & 0 & 0 & 0 & 0 & 1 & 0 & 0 & 1 & 0 & 0 & 0 & 0 & 0 & 1 & 1 & 0 & 0 & 1 & 0\end{array}$ $\begin{array}{llllllllllllllllllllllllllllllll}1 & 1 & 1 & 1 & 1 & 0 & 2 & 1 & 1 & 1 & 1 & 0 & 0 & 0 & 0 & 0 & 0 & 1 & 0 & 0 & 1 & 0 & 0 & 0 & 0 & 0 & 1 & 1 & 0 & 0 & 3 & 7\end{array}$ $\begin{array}{llllllllllllllllllllllllllllllll}1 & 1 & 1 & 1 & 3 & 0 & 1 & 1 & 1 & 3 & 1 & 0 & 0 & 0 & 0 & 0 & 0 & 1 & 0 & 0 & 1 & 0 & 0 & 0 & 0 & 0 & 1 & 1 & 0 & 0 & 1 & 0\end{array}$

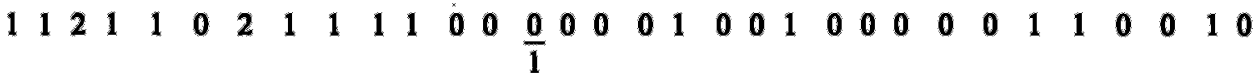

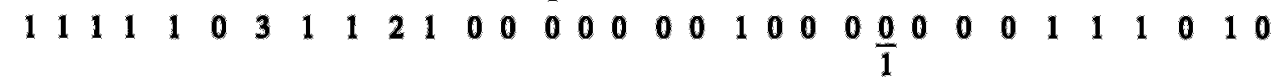
$\begin{array}{llllllllllllllllllllllllllllllll}1 & 1 & 0 & 1 & 1 & 0 & 1 & 1 & 1 & 1 & 1 & 0 & 0 & 0 & 1 & 0 & 0 & 1 & 0 & 1 & 1 & 0 & 0 & 0 & 0 & 0 & 1 & 1 & 1 & 0 & 2 & ?\end{array}$ $\begin{array}{llllllllllllllllllllllllllllllll}1 & 1 & 2 & 2 & 1 & 0 & 1 & 1 & 1 & 3 & 1 & 0 & 0 & 0 & 1 & 0 & 0 & 1 & 0 & 0 & 0 & 0 & 0 & 0 & 0 & 0 & 1 & 1 & 0 & 0 & 1 & 0\end{array}$

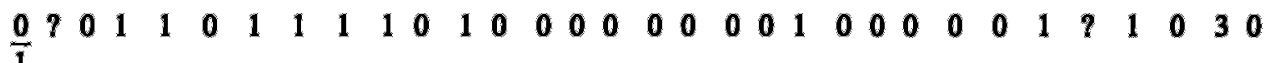
1

$\begin{array}{llllllllllllllllllllllllllllllll}1 & 1 & 2 & 1 & 2 & 0 & 1 & 1 & 2 & 2 & 1 & 0 & 0 & 1 & 0 & 0 & 0 & 0 & 0 & 0 & 1 & 0 & 0 & 0 & 0 & 0 & ? & ? & ? & ? & ? & ?\end{array}$ $\begin{array}{llllllllllllllllllllllllllllllll}1 & 1 & 1 & 1 & 3 & 0 & 1 & 1 & 1 & 1 & 1 & 0 & 0 & 1 & 0 & 0 & 0 & 0 & 0 & 0 & 1 & 0 & 0 & 0 & 0 & 0 & 1 & 1 & 0 & 0 & 1 & 1\end{array}$ $\begin{array}{llllllllllllllllllllllllllllllll}1 & 1 & 2 & 1 & 2 & 0 & 3 & 1 & 1 & 3 & 1 & 0 & 0 & 0 & 2 & 0 & 0 & 0 & 0 & 0 & 2 & 0 & 0 & 0 & 0 & 0 & 1 & 1 & 1 & 0 & 1 & 0\end{array}$ $\begin{array}{llllllllllllllllllllllllllllllll}1 & 1 & 2 & 1 & 3 & 0 & 3 & 1 & 1 & 3 & 1 & 0 & 0 & 0 & 2 & 0 & 0 & 0 & 0 & 0 & 2 & 0 & 0 & 0 & 0 & 0 & 1 & 1 & 1 & 0 & 2 & 1\end{array}$

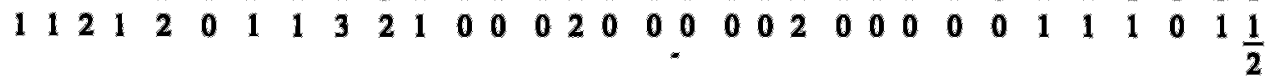


Appendix B. Cont.

Character no.

$\begin{array}{lllllllllllllllllllllll}1 & 1 & 1 & 1 & 1 & 1 & 1 & 1 & 1 & 1 & 2 & 2 & 2 & 2 & 2 & 2 & 2 & 2 & 2 & 2 & 3 & 3 & 3\end{array}$

Taxon

\begin{tabular}{lllllllllllllllllllllllllllllllllll}
\hline Aliaporcellana suluensis & 1 & 0 & 2 & 1 & 2 & 0 & 2 & 1 & 1 & 1 & 1 & 1 & 0 & 0 & 1 & 0 & 0 & 0 & 0 & 0 & 2 & 1 & 1 & 1 & 0 & 0 & 1 & 1 & 1 & 0 & 2 & 0 \\
Petrolisthes armatus & 1 & 0 & 2 & 1 & 2 & 0 & 3 & 1 & 1 & 2 & 1 & 1 & 0 & 0 & 1 & 0 & 0 & 0 & 0 & 0 & 2 & 0 & 1 & 1 & 1 & 1 & 1 & 1 & 1 & 1 & 2 & 0 \\
Petrolisthes lamarckii & 1 & 0 & 2 & 1 & 2 & 0 & 3 & 1 & 1 & 2 & 1 & 1 & 0 & 0 & 1 & 0 & 0 & 0 & 0 & 0 & 2 & 0 & 1 & 1 & 1 & 1 & 1 & 1 & 1 & 1 & 2 & 0 \\
Pisidia longicornis & 1 & 7 & 2 & 1 & 2 & 0 & 2 & 1 & 1 & 2 & 1 & 1 & 0 & 0 & 3 & 0 & 0 & 0 & 0 & 0 & 2 & 1 & 1 & 1 & 0 & 0 & 1 & 1 & 1 & 0 & 1 & $?$ \\
Polyonyx transversus & 1 & 0 & 2 & 1 & 2 & 0 & 2 & 1 & 1 & 2 & 1 & 1 & 0 & 0 & 1 & 0 & 0 & 0 & 0 & 0 & 2 & 1 & 1 & 1 & 0 & 0 & $?$ & $?$ & $?$ & $?$ & 7 & 0 \\
Hippa pacifica & 1 & 0 & 2 & 1 & 2 & 0 & 1 & 2 & 3 & 1 & 1 & 0 & 0 & 0 & 1 & 0 & 0 & 0 & 0 & 0 & 2 & 0 & 0 & 0 & 0 & 0 & 0 & 0 & 1 & 0 & 0 & 0 \\
Portunus pelagicus & 2 & 2 & 0 & 1 & 2 & 0 & 1 & 1 & 2 & 1 & 1 & 0 & 1 & 1 & 1 & 0 & 0 & 0 & 0 & 2 & 1 & 0 & 0 & 0 & 0 & 0 & 2 & 0 & 1 & 0 & 0 & 0 \\
Menaethius monoceros & 2 & 1 & 1 & 1 & 3 & 0 & 1 & 1 & 1 & 1 & 1 & 1 & 1 & 0 & 1 & 0 & 0 & 0 & 0 & 2 & 1 & 0 & 0 & 0 & 0 & 0 & 2 & 0 & 1 & 0 & 0 & 0 \\
Homarus americanus & 0 & 1 & 2 & 2 & 2 & 0 & 1 & 1 & 1 & 3 & 1 & 1 & 0 & 0 & 1 & 0 & 0 & 0 & 0 & 0 & 1 & 0 & 0 & 0 & 0 & 0 & 0 & 0 & 1 & 0 & 0 & 1 \\
Panulinus argus & 0 & 0 & 0 & 0 & 0 & 0 & 0 & 0 & 0 & 0 & 0 & 0 & 0 & 0 & 0 & 0 & 0 & 0 & 0 & 0 & 0 & 0 & 0 & 0 & 0 & 0 & 0 & 0 & 1 & 0 & 0 & $?$ \\
Thenus orientalis & 0 & 0 & 0 & 0 & 0 & 0 & 0 & 0 & 0 & 1 & 0 & $?$ & 0 & 0 & 0 & 0 & 0 & 0 & 0 & 0 & 0 & 0 & 0 & 0 & 0 & 0 & 2 & 0 & 1 & 0 & 0 & 0 \\
Pacifastacus leniusculus & 0 & 0 & 2 & 1 & 3 & 0 & 1 & 1 & 1 & 0 & 1 & 1 & 0 & 0 & 0 & 0 & 0 & 0 & 0 & 0 & 1 & 0 & 0 & 0 & 0 & 0 & 0 & 0 & 1 & 0 & 0 & 1
\end{tabular}

